\title{
Analysis of Impacts of RMB's Exchange Fluctuation on Export of China's High-tech Products--Based upon ADF Test
}

\author{
Ludmila Sterbova ${ }^{1, a}$, Xinying Liu ${ }^{2, b}$, Xuan Liü ${ }^{3, c}$ \\ ${ }^{1}$ Department of International Relationship, University of Economics in Prague, Czech Republic \\ ${ }^{2}$ Department of International Economics and Trade, Shandong University of Finance and \\ Economics, Jinan, Shandong Province, 250000, China \\ ${ }^{2}$ Department of International Economics and Trade, Shandong University of Finance and \\ Economics, Jinan, Shandong Province, 250000, China \\ aemail: ludmila.sterbova@vse.cz, bemail: sheila_guo1988@hotmail.com, \\ cemail: liuxuan92@yeah.net
}

Keywords: Exchange Fluctuation of RMB; Export of High-tech products; ADF Test; J Curve

\begin{abstract}
In 2014, China’s export of high-tech products maintained a rapid growth, reached $\$ 645.3$ billion and contributed greatly to the development of the high technology industry as well as the industrial restructuring in China. Then in 2015 it appears a slight devaluation. It is critical for us to conduct research on the impacts of RMB appreciation to China's export of high-tech products under the conditions. Based on the background of RMB fluctuations, starting from the relationship between RMB exchange rate and China's export of high-tech products trade, the author applies the unit root test, co integration test and Granger causality test to analyzing the effect of RMB exchange rate on China's high-tech products export trade and worked out the relevant proposals.
\end{abstract}

\section{Introduction}

\section{Current Situation of RMB Exchange Rate}

Before exchange rate formation mechanism reform, exchange rate of RMB against the US dollar central was 8.2765. After the RMB exchange reform, with reference to a basket of currencies exchange rate adjustment, at the same time it announced that the RMB exchange rate had adjusted to: 1 US dollar against 8.11 yuan and kept appreciating. Then it quickly adjusted to 1 US dollar against 7.998 yuan in May, since then the exchange rate of RMB broke the mark of 8 . The central bank had the second exchange reform in June of 2010, and the exchange rate of RMB kept further appreciation. By the end of 2013,exchange rate of RMB against the US dollar central parity was 6.0969 yuan / dollar. Continued to 2014, RMB depreciated slightly, RMB exchange rate by the end of 20146.1224 yuan / dollar fell to 6.4936 yuan / dollar at the end of 2015, depreciation up to $6.06 \%$.

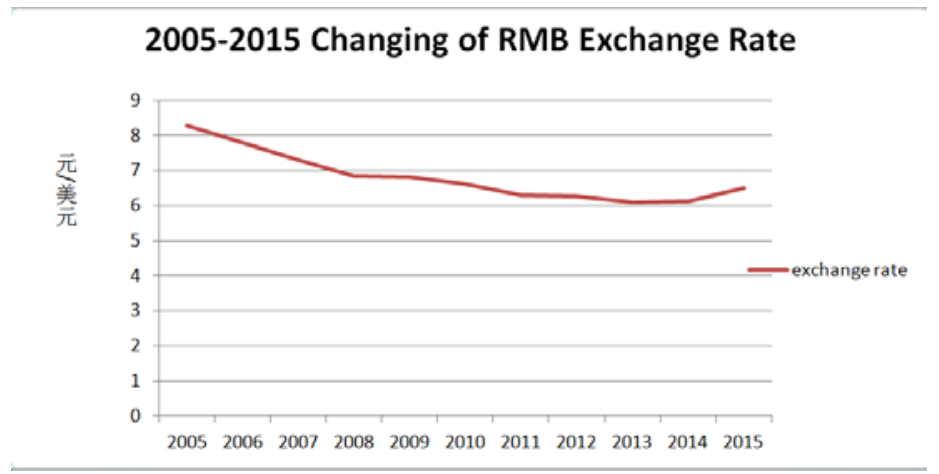

Fig.1. Changing of RMB Exchange Rate

\section{Current Situation of High Technology Industry's Export}

We can see from the export volume of high-tech industry, the export of Chinese high-tech products is 415.96 billion US dollars in the year of 2005, but the export reached to 655.21 billion 
US dollars in the year of 2015, the average annual growth rate is $5.7 \%$ in the past 10 years. Secondly, the net exports had trade surplus from 2005 to 2015. The trade surplus amounted to 107.15 billion US dollars in 2015 from 20.84 billion US dollars in 2005.

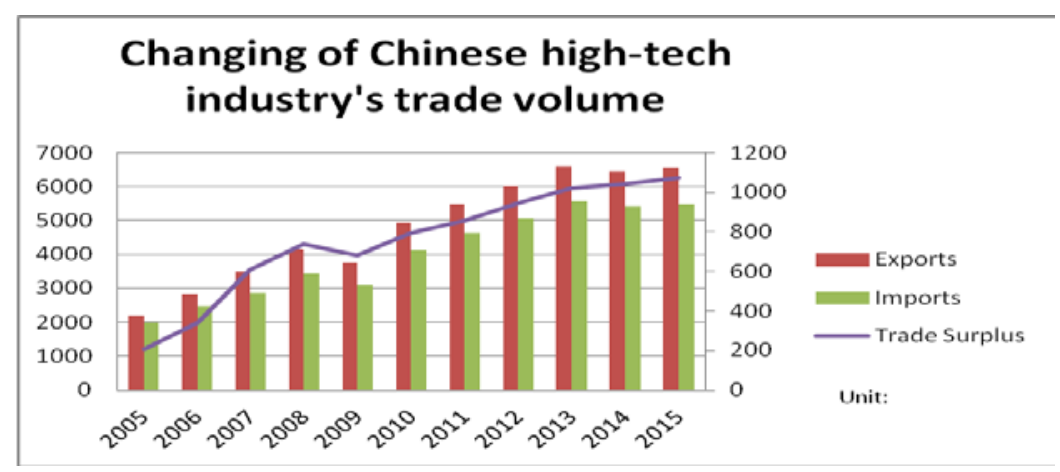

Fig.2. Changing of Chinese high-tech industry's trade volume

In recent years, the main features of the export trade of Chinese high-tech industry can be summed up in four areas of export trading forms, export structure, the main part of export trade and export markets.

\section{Export Trading Forms}

China's high-tech products export trade mainly in processing trade, and the processing trade is divided into feed processing trade and processing and assembling trade. While exports of processing trade way has a dominant position in the export of high-tech products, but we can see that the data presented from the Chinese Ministry of Commerce and the Chinese Ministry of Science: In 2005 the proportion of processing trade exports of Chinese high-tech industry was more than $80 \%$, but $65.33 \%$ in 2015 , the trend of unstable downward. It can also be clearly seen from Chart 1.2.2, that from 2005 to 2014, the proportion of general trade exports raised from $7.2 \%$ to $24.2 \%$, showing rising trend.

\section{Export Structure}

We can see from the data of Chinese high-tech industry's export structure, that in 2005 exports of computer communication products was 136.215 billion US dollars, accounted for 62.41 percent of total exports of high-tech products. Cause the People's Republic of China Ministry of Commerce data updated to 2013, so all the analysis is based on the data of 2013. In 2013, the exports of computer communication products was 439.09 billion US dollars, accounted for $66.50 \%$ of total exports of high-tech products, trade surplus reached for 102.14 billion US dollars. Not only changed the long-term phenomenon of trade deficit, but also widening the trade surplus amount. The largest increasing products of exports was electronic technology products in 2013, growth of 34.74\%. And photoelectric technology products and materials technology products, the largest increasing products of exports in 2005, had a greater proportion of the decline to2013. Chinese exports of high-tech products dependents on computer and communication technology products to a greater extent, and other categories of technology products lack comparative advantage in the international market.

\section{The Main Part of Export Trade}

From the perspective of the main part of export trade, foreign-funded enterprises is the main part of high-tech products' export, including Sino-foreign cooperation, joint ventures, wholly foreign-owned and other forms. As of the latest Commerce Department data, foreign dominant position in Chinese field of high-tech exports is rising, and the amount of export increased year by year since the exchange rate reform in 2005. But the share of state-owned enterprises in exports has declined year by year. The proportion of foreign-funded high-tech exports in 2013 increased to $85.2 \%$. On the other hand, the proportion of state-owned enterprises in high-tech exports are showing a rapid decline: from $10.4 \%$ in 2005 , fell to $5.64 \%$ in 2013 . Although the Chinese high-tech products has been the dominant force concentrated in foreign-funded enterprises, from the point view of processing trade, foreign companies will not put the main platform for independent research and development carried out in China. But monopoly, patents and technology stay in 
foreign countries, only producing mainly in processing trade in China.

\section{Export Markets}

Chinese high-tech products export market is relatively concentrated in some developed countries and regions. Chinese Ministry of Commerce data shows that, US, EU, Hong Kong China, Japan and ASEAN has always occupied a high market share, and this situation changed little since 2005. Countries and regions which Chinese high-tech products export most in 2005, is US, export share of $24.2 \%$ in the total amount of high-tech exports the same year, up to 26.71 billion US dollars. This situation has changed in 2009, Hong Kong had became China's first high-tech products export market, its export share of $23.6 \%$ in the amount of high-tech exports. And recent data shows that the export trade proportion of ASEAN region gradually increased, although slowly.

\section{Empirical Analysis}

\section{Selection of Empirical Analysis Model \\ 1)Model Selection}

In this paper, we use Chinese high-tech products export trade monthly data published in Chinese Ministry of Commerce, China Foreign Trade Division, Chinese Ministry of Science and Technology, and monthly Real Effective Exchange Rate data published in People's Bank of China from July 2005 to December 2015, as the data set of analysis. Through ADF test method, observing whether it is the long-term dynamic equilibrium relationship between Chinese high-tech exports and the RMB exchange rate, and to examine the relationships between variables in short-term through error correction model (ECM). In this paper, we use the exchange rate index for the Real Effective Exchange Rate(REER). And also indirect quotation, that exchange rate appreciation of the RMB. Real Effective Exchange Rate is the effective exchange rate adjusted after price changes, it can better measure of a country's currency relative to the average currency exchange rates and eliminate the influence of other factors of exchange rate changes, reflecting a country's overall competitiveness in the international arena. Among them, REER represents Real Effective Exchange Rate; EX represents the nominal exports of Chinese high-tech products; REX represents the real exports of Chinese high-tech products; CPI(Consumer Price Index) represents inflation. LNREX, LNREER represent actual exports, the logarithm of the Real Effective Exchange Rate; $\triangle$ LNREX, $\triangle$ LNREER were LNREX, LNREER's first difference.

\section{2)Data Processing}

In this paper, to eliminate the influence of inflation and rising prices on the RMB exchange rate fluctuations, adjustment of Chinese high-tech product exports, use CPI divided by EX, calculate the REX, in order to more accurately reflect the impact of the change of REER on China's exports trade of high-tech products. Meanwhile, all the above CPI converted into the CPI based on the period of July 2005.

\section{Augmented Dicker-Fuller (ADF) Test \\ 1)Unit Root Test}

Before the empirical study of model, we should do unit root test for the above data, to verify whether the data has stability, and avoid the result of "spurious regression". Table 1 gives the unit root test value of LNREX, LNREER. The results show that: from July 2005 to December 2015, the first difference of sequence variables' ADF statistic are much less than the critical value at the significance level of 1\%, 2\%, 5\%. LNREER, LNREX are order one sequence I(1), comply with the requirements of order difference stationary in the framework of vector autoregression model analysis. 
Table 1 Unit root test of LNREX, LNREER

\begin{tabular}{|l|l|c|c|c|c|c|}
\hline & \multicolumn{1}{|c|}{$\begin{array}{l}\text { Type of } \\
\text { Test }\end{array}$} & ADF & \multicolumn{3}{|c|}{ Threshold } & Test \\
\hline Variable & $(\mathrm{C}, \mathrm{T}, \mathrm{K})$ & Test Value & $1 \%$ & $5 \%$ & $10 \%$ & Result \\
\hline LNREX & $(\mathrm{C}, 0,0)$ & -1.590844 & 3.495677 & -2.890037 & -2.582041 & $\begin{array}{c}\text { Not } \\
\text { Steady }\end{array}$ \\
\hline LNREER & $(\mathrm{C}, 0,0)$ & -0.103739 & -3.489117 & -2.88719 & -2.580525 & $\begin{array}{c}\text { Not } \\
\text { Steady }\end{array}$ \\
\hline$\triangle 1$ LNREX & $(\mathrm{C}, 0,0)$ & -11.27447 & -4.050509 & -3.454471 & -3.152909 & Steady \\
\hline$\triangle 1$ LNREER & $(\mathrm{C}, 0,0)$ & -11.16296 & -4.042042 & -3.450436 & -3.150549 & Steady \\
\hline
\end{tabular}

Note: $\Delta 1$ represents the first difference; $\mathrm{C}, \mathrm{T}$ and $\mathrm{K}$ in the test form(C,T,K) represent including constant term, time trend and lag order; 0 in the test form $(\mathrm{C}, 0,0)$ represent not including the constant term or time trend.

\section{Cointegration}

According to ADF test results, we use two-step method of EG test.

First, do single integration test for LNREX and LNREER, prosequence LNREX and LNREER are non-steady sequence, but the first difference sequence $\triangle$ LNREX and $\triangle$ LNREER are steady sequence. So $\triangle \mathrm{LNREX}$ and $\triangle \mathrm{LNREER}$ are order one sequence, meet the premise of Cointegration.

Second, do ordinary least square regression for LNREX and LNREER, do unit root test for their residuals e. We can see the result in Table 2, the magnitude of the test statistic is -8.936893, less than the threshold -3.490772 of significantly level of $1 \%$. So it can be estimated that the residual series e is stationary series, and LNREX and LNREER are cointegrated.

Table 2 The results of sequence e's ADF test

\begin{tabular}{|c|c|c|c|}
\hline ADF Test Statistic & -8.936893 & 1\% Critical Value & -3.490772 \\
\hline & & 5\% Critical Value & -2.887909 \\
\hline & & $10 \%$ Critical Value & -2.580908 \\
\hline
\end{tabular}

\section{Error Correction Model(ECM)}

ECM reflects the degree of deviation from the long-run equilibrium relationship between the variables in the short-term fluctuations, it is named equalization error. It has proven that LNREX and LNREER are cointegrated, so we can establish ECM.

Table 3 Estimated and associated test results of ECM

\begin{tabular}{|c|c|c|c|c|}
\hline Variable & Coefficient & Std.Error & t-Statistic & Prob. \\
\hline C & -2.575353 & 0.722405 & -3.564971 & 0.0005 \\
\hline LNREX(-1) & 0.439682 & 0.086228 & 5.099055 & 0.0000 \\
\hline LNREER & 3.956891 & 0.971726 & 4.072022 & 0.0001 \\
\hline LNREER(-1) & -5.586868 & 1.477716 & -3.780744 & 0.0003 \\
\hline LNREER(-2) & 2.612692 & 0.997640 & 2.618874 & 0.0101 \\
\hline R-squared & 0.670082 & Mean dependent var & \multicolumn{2}{|c|}{3.489802} \\
\hline Adjusted R-squared & 0.657749 & S.D.dependent var & 0.254012 \\
\hline S.E.of regression & 0.148602 & Akaike info criterion & \multicolumn{2}{|c|}{-0.931469} \\
\hline Sum squared resid & 2.362846 & Schwarz criterion & \multicolumn{2}{|c|}{-0.810108} \\
\hline Log likelihood & 57.16227 & F-statistic & \multicolumn{2}{|c|}{54.33086} \\
\hline Durbin-Watson stat & 1.926717 & Prob(F-statistic) & \multicolumn{2}{|c|}{0.000000} \\
\hline
\end{tabular}

The equation can be obtained according to the results of ECM:

LNREX=-2.575353+0.439682*LNREX(-1)+3.956891*LNREER-5.586868*LNREER(-1)+2.61 $2692 *$ LNREER(-2)

It can be derived from the equation, and follows is the relationship between RMB real exchange rate changes and China's high-tech exports:

First, the current real effective exchange rate has a certain positive impact on exports of Chinese high-tech products. In equation (1), the factor of LNREER is 3.956891, it shows a decrease in the month of RMB real effective exchange rate (the exchange rate rises 1\%), exports of Chinese high-tech product will be reduced 3.956891\%. 
Second, lagged one real effective exchange rate has a negative impact on the current Chinese high-tech products export trade. In equation (1), the factor of LNREER(-1) is -5.586868, it shows a decrease in the real effective exchange rate last term (the RMB real effective exchange rate appreciated by $1 \%$ last month), exports of Chinese high-tech product will increase $5.586868 \%$.

Third, lagged two RMB real effective exchange rate has a positive effect on current Chinese high-tech products export trade. In equation (1), the factor of LNREER(-2) is 2.612692, it shows a increse in the real effective exchange rate lagged two (Exchange rate reduced by 1\%), exports of Chinese high-tech product will increase $2.612692 \%$.

Fourth, the elastic coefficients of current, lagged one, lagged two were 3.956891 and -5.586868,2.612692, significantly greater than unity elasticity. It can be seen that, impact of exchange rate changes on Chinese high-tech exports has a significantly lagged effect. And because the sign of real effective exchange rate's elastic coefficients has both positive and negative, it on behalf of if the RMB exchange rate appreciated, the RMB real effective exchange rate will decline, then it will first bring the total increase in exports of Chinese high-tech products, with the adjustment for price of economic agents, the relationship of supply and demand will have fluctuation in high-technology products' international market. Total exports of high-tech products will also be reduced.

It can be derived from the equation that, the long-term tendency of the impact of RMB exchange rate changes on China's high-tech exports (LRP) is 0.982715. It means that, if it is a decrease in the month of RMB real effective exchange rate (the exchange rate rises 1\%), exports of Chinese high-tech product will be reduced $0.982715 \%$.

\section{Conclusion}

All the above analysis shows that, the impact of RMB exchange rate fluctuations on Chinese high-tech products export in line with "anti-J-curve effect" theory. In the test of ADF, the current real effective exchange rate has a positive effect on the export of Chinese high-tech products, showing negative impact on lagged one, but showing positive impact on lagged two. With the appreciation of RMB exchange rate, export of high-tech products will increase in the short utility, but with the appreciation of RMB exchange rate, export of high-tech products will decline in the long term utility. First, current account situation of high-tech products will improve than the original, the export will increase in a period of time; then with pass of time, RMB appears devaluation, and have negative impact on export of high-tech products eventually. Over the next predictable timeframe, pressure on the RMB exchange rate fluctuations will always exist.

\section{Acknowledgement}

In this paper, the research was sponsored by the Studying Aboard Foundation of Shandong Province.

\section{References}

[1] Lu Sang. Impact Analysis of RMB Exchange Rate Changes on China's Export and Import of the Trade[D] . Hebei Normal University, 2012.

[2] Hao Li. Empirical Research OF RMB Exchange Rate Impact on Chinese Imports and Exports[D] . Northwest A\&F University, 2013.

[3] X.L. Shang. Influencing Factors of Chinese High-tech Products Export[D]. Hebei University of Economics, 2013.

[4] X.Y. Liu, Bei Xiao. The Impact of RMB appreciation on China's Export Trade[J]. Shandong University of Finance, 2012,(06) :70-77.

[5] M.L. Yu. Analysis of RMB Appreciation on Export of Agricultural Products in Shandong 
Province[J]. Heilongjiang Foreign Trade, 2009,(02):40-42.

[6] Y.N. Li. China Foreign Economic and International Payments Study[M]. Beijing International Cultural Publishing Company,1991.

[7] Z.Y. Dai. Elastic Analysis of China's Trade Balance:1981-1995[J]. Economic Research, 1997,(7):32-41.

[8] Z.Y. Xie, Z.Y. Xu. An Empirical Analysis of Relationship Between RMB Exchange Rate and Import and Export Trade Growth since the Asian Financial Crisis[J]. International Finance Research, 1999(07).

[9] Zh.Y. Xie, C.M. Zh. Analysis of the Impact of RMB Appreciation on the High-tech Industry[J] . Chinese High-tech Enterprises, 2009,(20):1-3. 